\title{
Behaviors of Ribonuclease in Tobacco Mosaic Virus-infected Nicotiana glutinosa Leaves*
}

\author{
Kamehisa Matsushita** and Hidetoshi Shimokawa** \\ 松下亀久**・下川英俊** : タバコモザイクウイルス感染の Nicotiana \\ glutinosa 植物葉に拈けるリボヌクレアーゼの挙動*
}

\begin{abstract}
The activities and the electrophoretic patterns of ribonuclease (RNase) in leaves of Nicotiana glutinosa plant after mechanical injury, various chemical treatments and/or tobacco mosaic virus (TMV) -inoculation were investigated. The enzyme activity increased and reached a maximum $16 \mathrm{hr}$ after mechanical injury. When the injured leaves were inoculated with TMV, the infectivity also showed a maximum value $16 \mathrm{hr}$ after mechanical injury. TMV-inoculation induced an increase in the enzyme activity, but the effect was dependent on the inoculum concentration.

The enzyme was separated into two isozymes, $\mathrm{M}$ and $\mathrm{F}$, by polyacrylamide gel electrophoresis. Mechanical injury and TMV-inoculation of the leaves led to an increase of the activity of $\mathrm{M}$ and $\mathrm{F}$ isozyme, respectively.

Bentonite or sodium dextran sulfate inhibited $\mathrm{M}$ isozyme activity, while yeast RNA or eosine $\mathrm{Y}$ increased $\mathrm{F}$ isozyme activity. However, these chemicals inhibited TMV-infectivity.

When the plants were kept at $35 \mathrm{C}$ after TMV-inoculation, $\mathrm{F}$ isozyme activity was not detected, but a new isozyme band appeared. However, when the same plants were transfered to an incubator maintained at the lower temperature, $21 \mathrm{C}$, the new band was not detected, but $\mathrm{F}$ isozyme appeared again.

The significance of these results was discussed with respect to a possible role of RNase in the infection of TMV.
\end{abstract}

(Received September 9, 1982)

Key Words : Nicotiana glutinosa, RNase, electrophoresis, TMV.

\section{Introduction}

It has been generally thought that ribonuclease (RNase) participates in the hydrolysis of ribonucleic acid. However, Markham and Strominger ${ }^{9)}$ reported that RNase may also be concerned in the processes of synthesis and rearrangement of ribonucleic acids. Diener ${ }^{4}$ repoted that in several plants rubbing with carborundum of and inoculation with tobacco mosaic virus (TMV) of leaves resulted in increase of RNase activity.

The present study was undertaken to shed some light on the function of the enzyme in Nicotiana glutinosa leaves infected with TMV. Here, we describe on the

* This work was supported partly by a Grant-in-Aid (No. 00434030) for Scientific Research from the Ministry of Education, Science and Culture of Japan.

** Laboratory of Biology, Fukuoka Dental College, Fukuoka 814-01, Japan 福岡歯科大学生物学教室 
changes in the activities and the electrophoretic patterns of RNase isozymes in $N$. glutinosa leaves subjected to injury, chemical treatment, and/or TMV-inoculation.

\section{Materials and Methods}

Plants and virus. Nicotiana glutinosa was used in this investigation. They were grown in a greenhouse maintained at $27 \mathrm{C}$ under natural lighting conditions. TMV was purified from the sap of systemically infected Nicotiana tabacum var. White Burley by the method of Steere ${ }^{14)}$, and unless otherwise stated, TMV was used in the concentration of $50 \mu \mathrm{g} / \mathrm{ml}$ in the present study.

Chemicals. The following chemicals were used; bentonite (Katayama Chemical Co.), eosine Y (Katayama Chemical Co.), sodium dextran sulfate (Pharmacia Fine Chemicals), and yeast RNA (Sigma Chemical Co.). Bentonite was purified by the method of Fraenkel-Conrat ${ }^{5)}$.

Mechanical injury and chemical treatment of leaves. Mechanical injuries of the leaves of $N$. glutinosa were carried out as follows. Half-leaves dusted with 400-mesh carborundum were rubbed with cotton pads moistened with $0.1 \mathrm{M}$ phosphate

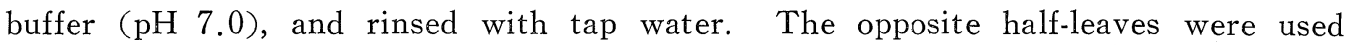
without rubbing as a control. Chemical treatments were carried out by rubbing carborundum-dusted half-leaves with cotton pads moistened with each chemical, except that bentonite treatment was applied by rubbing bentonite-dusted half-leaves with cotton pads. The opposite half-leaves were used without chemical treatment as a control.

Infectivity assay. Infectivity of TMV was measured by the local lesion assay. Injured or chemical-treated half-leaves were dusted with carborundum, and TMV was inoculated by rubbing with cotton pads. The healthy opposite control half-leaves were also inoculated with TMV after dusting with carborundum. All the half-leaves were rinsed with tap water, and kept at $27 \mathrm{C}$ in a greenhouse. The lesions which appeared 2 days after inoculation were counted. Twelve half-leaves were used in each experiment and all experiments were repeated 3 times.

Extraction and measurement of $\boldsymbol{R} \boldsymbol{N A}$. RNA of leaf tissues was prepared by the method of Schlegel ${ }^{13)}$. Leaf tissue was ground with 4 times their weight of a mixture of $1 \%$ tetrasodium pyrophosphate and water-saturated phenol (1:1) in a mortar and pestle, and centrifuged $(2,300 \times g$ for $15 \mathrm{~min})$, and the resultant aqueous phase was washed with ether 3 times. The aqueous phase was precipitated by addition of ethanol, and the precipitate was dissolved in $10 \mathrm{ml}$ of $0.1 \mathrm{M}$ phosphate buffer ( $\mathrm{pH}$ 7.0). In the measurement of RNA content, the RNA solution was diluted 10-fold with the same buffer, and read spectrophotometrically.

Extraction of RNase and assay of RNase activity. Extraction of RNase was carried out according to the method of Bagi and Farkas ${ }^{1)}$. One gram of the leaf tissue was ground with $3 \mathrm{ml}$ distilled water in a mortar, and centrifuged $(20,000 \times g$ for $10 \mathrm{~min}$ ). The supernatant was used as the enzyme preparation in the present study. The $\mathrm{pH}$ optimum of the enzyme occurred at 5.1 (data not shown). According to the method of Frisch-Niggemeyer and Reddi ${ }^{6}$, the enzyme activity was determined by measuring with a spectrophotometer the absorption of the breakdown product of 
yeast RNA which was not precipitated by acid. Spectrophotometric measurement was carried out using a Multipurpose Recording Spectrophotometer MPS-50 L (Shimadzu).

Gel electrophoresis. Polyacrylamide gel electrophoresis of the enzyme preparation was carried out with $7.5 \%$ polyacrylamide gels at $\mathrm{pH} 8.0$ according to the method of Davis ${ }^{3}$. Sample gels $(200 \mu 1)$ containing $75 \mu 1$ of the enzyme preparation were layered on $4 \times 60 \mathrm{~mm}$ gels. Electrophoresis was performed at $4 \mathrm{C}$ for about 1.5 hr at $3 \mathrm{~mA} / g e l$. Detection of the enzyme in the gel was performed by a slightly modified method of Wilson ${ }^{17)}$. After the electrophoresis, the gels were preincubated with $10 \mathrm{ml}$ of $0.1 \mathrm{M}$ acetate buffer ( $\mathrm{pH} \mathrm{5.1)}$ in test tubes at $37 \mathrm{C}$ for $10 \mathrm{~min}$ and then incubated with $10 \mathrm{ml}$ of $0.5 \%$ yeast RNA in the same buffer for $30 \mathrm{~min}$. These gels were then incubated with $0.1 \mathrm{M}$ acetate buffer for $5 \mathrm{~min}$, and stained with $0.2 \%$ acridine orange (or $0.2 \%$ toluidine blue) in $7 \%$ acetic acid and further destained with $7 \%$ acetic acid.

\section{Results}

\section{Effects of mechanical injury and TMV-inoculation on RNase activity and RNA content}

Effects of mechanical injury on RNase activity of $N$. glutinosa leaves were investigated. The enzyme activity enhanced with time after injury and reached a maximum at $16 \mathrm{hr}$ (Fig. 1). The level of increased enzyme activity was maintained for at least $60 \mathrm{hr}$. In the period showing the plateau on the enzyme activity curve in Fig. 1, no apparent injury effect on the leaves after the mechanical treatment was observed. When the leaves were inoculated with TMV at various times after the injury, the viral infectivity also reached a maximum $16 \mathrm{hr}$ after injury. A time-course

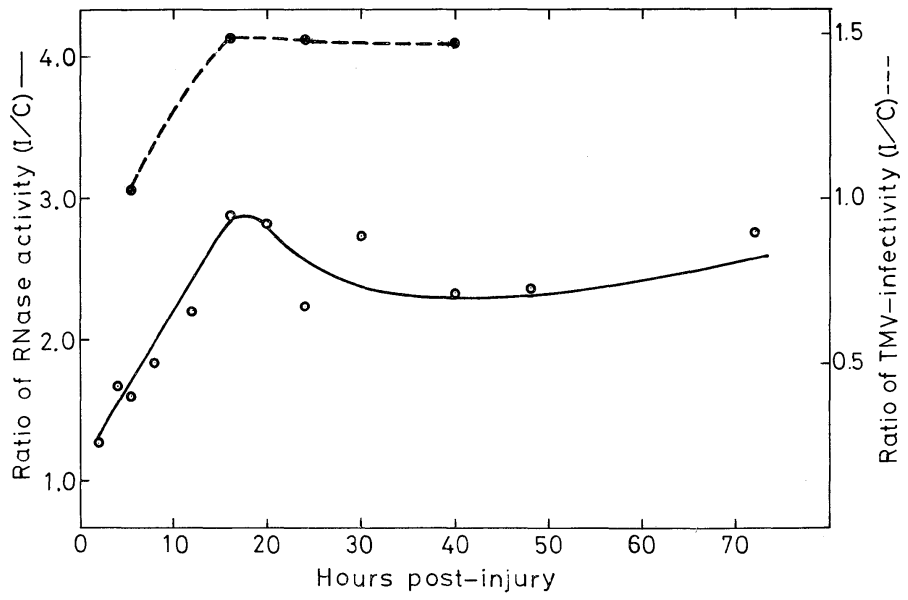

Fig. 1. Ratio of RNase activities in injured leaves (I) and non-injured ones (C) of $N$. glutinosa, and ratio of TMV-infectivity in I and $C$ inoculated with TMV. RNase activity and TMV-infectivity were determined as described in Materials and Methods. 
study of the enzyme activity of $N$. glutinosa leaves inoculated with TMV was carried out (Fig. 2). The enzyme activity increased slowly with time after inoculation, and the leaves inoculated with a high concentration of TMV $(50 \mu \mathrm{g} / \mathrm{ml})$ showed higher activity as compared to leaves inoculated with a low concentration $(15 \mu \mathrm{g} / \mathrm{ml})$. However, when the leaves were inoculated with heat-inactivated TMV (heated for 10 min at $100 \mathrm{C}$ ), no increase of the enzyme activity was observed during $70 \mathrm{hr}$ after inoculation. Thus, it was suggested that the increase of the enzyme activity induced by TMV was dependent on the concentration of active TMV.

RNA contents of non-injured (healthy) leaves and injured ones showed almost the same values, in spite of the increase of the enzyme activity in injured leaves in the period measured after injury (data not shown).

\section{Gel electrophoresis}

The results of the electrophoretic analyses of the enzyme from $N$. glutinosa leaves are shown in Fig. 3. In the present study, the enzyme was separated into two isozyme bands; one main broad band (designated as $\mathrm{M}$ ) in the middle part of the gel, and the other narrow band (designated as F) which moved more rapidly than the former. In addition to these two isozyme bands, one more band was detected near $\mathrm{F}$ band at times. After the injury of leaves, however, $M$ band expanded along with the increase of the enzyme activity, but no change of F band was observed. On the other hand, it was found that in the leaves infected with TMV these isozymes showed different electrophoretic patterns from those of the isozymes of the injured leaves. That is; the remarkable increase of $\mathrm{F}$ band was observed $48 \mathrm{hr}$ after TMV-inoculation, but $M$ band was not different from that of the injured leaves. Moreover, the higher the concentration of TMV used for inoculation, the greater $F$ band. This result corresponded with the increase in enzyme activity induced by inoculating with TMV as shown in Fig. 2.

To determine whether $\mathrm{M}$ and $\mathrm{F}$ isozymes have phosphatase activity, after the electrophoresis the gel was incubated with calf thymus DNA $(1 \mathrm{mg} / \mathrm{ml})$. However,

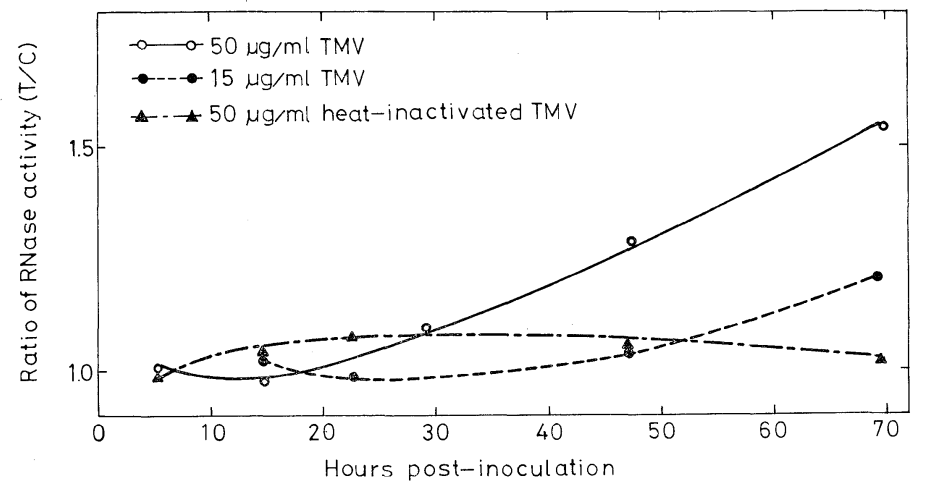

Fig. 2. Ratio of RNase activities in $N$. glutinosa leaves inoculated with TMV (T) and mock-inoculated with $0.1 \mathrm{M}$ phosphate buffer, $\mathrm{pH} 7.0$ (C). RNase activity was determined as described in Materials and Methods. 
$M$ and $F$ bands were not observed in the gel (data not shown). Thus, no phosphatase activity of both isozymes were detected.

\section{Effects of chemicals}

RNase preparations from half-leaves of $N$. glutinosa treated with various chemicals were examined for total RNase activity and the RNase isozyme pattern (Table 1 and Fig. 4). In some experiments, chemically treated half-leaves were subsequently inoculated with TMV to study the effects of these chemicals on TMV-infectivity. In such the experiments TMV was inoculated at the time of highest or lowest enzyme activity in chemically treated half-leaves of $N$. glutinosa. As shown in Table 1, all chemicals inhibited TMV. infectivity. Bentonite and sodium dextran sulfate showed inhibitory effects on the enzyme activity. When the enzyme activity was inhibited, M isozyme in the gel was reduced in band width (Fig. 4). In contrast, yeast RNA and eosine Y showed stimulative effects. In this case, the band of the isozyme showed a different profile in which $\mathrm{F}$ isozyme increased the band width (Fig. 4).

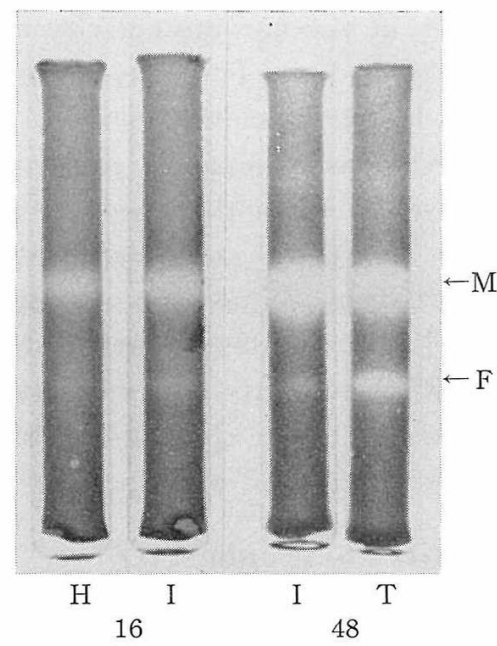

Fig. 3. Electrophoretic patterns of RNase isozymes in $N$. glutinosa leaves. RNase samples were extracted at the indicated times (hr) after mechanical injury or TMVinoculation. $\mathrm{H}, \mathrm{I}$ and $\mathrm{T}$ are RNase samples from healthy leaves, leaves mock-inoculated with $0.1 \mathrm{M}$ phosphate buffer, $\mathrm{pH} 7.0$, and leaves inoculated with TMV, respectively. $\mathrm{M}$ and $\mathrm{F}$ show the isozyme bands, respectively.

Table 1. Effects of chemicals on RNase activity and TMV-infectivity in N. glutinosa leaves

\begin{tabular}{lcccc}
\hline \hline Chemicals & RNase activity & $\%$ of control & $\begin{array}{c}\text { Infectivity } \\
\text { (lesion }\end{array}$ & numbers/half-leaf) \\
\hline control & 37.8 & & $50.0 \pm 3.0$ & 62.0 \\
Bentonite & 21.9 & 57.9 & $31.0 \pm 5.0$ & \\
control & 85.7 & & $72.2 \pm 1.7$ & 66.8 \\
$\begin{array}{l}\text { Sod. dextran } \\
\text { sulfate }\end{array}$ & 76.6 & 89.4 & $48.2 \pm 1.8$ & \\
control & 40.4 & & $71.9 \pm 6.6$ & 22.4 \\
Yeast RNA & 47.6 & 117.9 & $16.1 \pm 2.3$ & \\
control & 35.0 & & $21.9 \pm 7.7$ & 41.4 \\
Eosine Y & 45.3 & 129.4 & $10.3 \pm 5.6$ & \\
\hline
\end{tabular}

Half-leaves of $N$. glutinosa were treated with the following chemicals: Bentonite, Sod. dextran sulfate $(0.1 \mathrm{~g} / \mathrm{ml})$, Yeast RNA $(10 \%)$ and Eosine Y $\left(10^{-4} \mathrm{M}\right)$. The opposite half-leaves (control) were treated with distilled water. Subsequently, all half-leaves were inoculated with TMV at intervals; $24 \mathrm{hr}$ (Sod. dextran sulfate), $48 \mathrm{hr}$ (Bentonite, Eosine Y), and $88 \mathrm{hr}$ (Yeast RNA) after treatment with each chemical indicated in parentheses. RNase activity and TMV-infectivity were determined as described in Materials and Methods. Each value is the mean of three experiments. * statistically significant at the $1 \%$ level. 


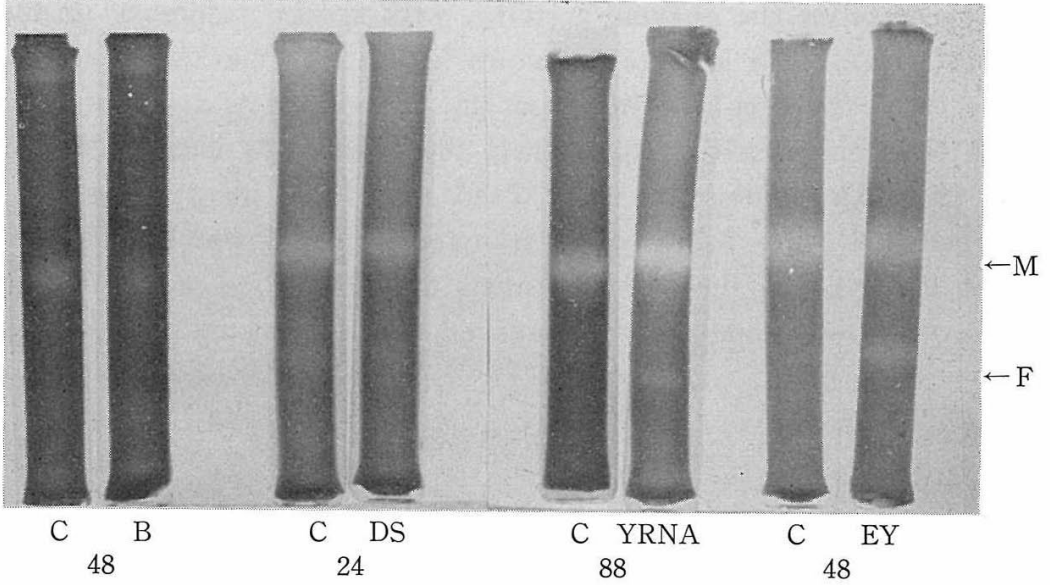

Fig. 4. Electrophoretic patterns of RNase isozymes in $N$. glutinosa leaves treated with various chemicals. B: Bentonite, DS: Sod. dextran sulfate, YRNA: Yeast RNA, EY: Eosine Y, C: control. Figures show the times (hr) after chemical treatments. M and $\mathrm{F}$ show the isozyme bands, respectively.

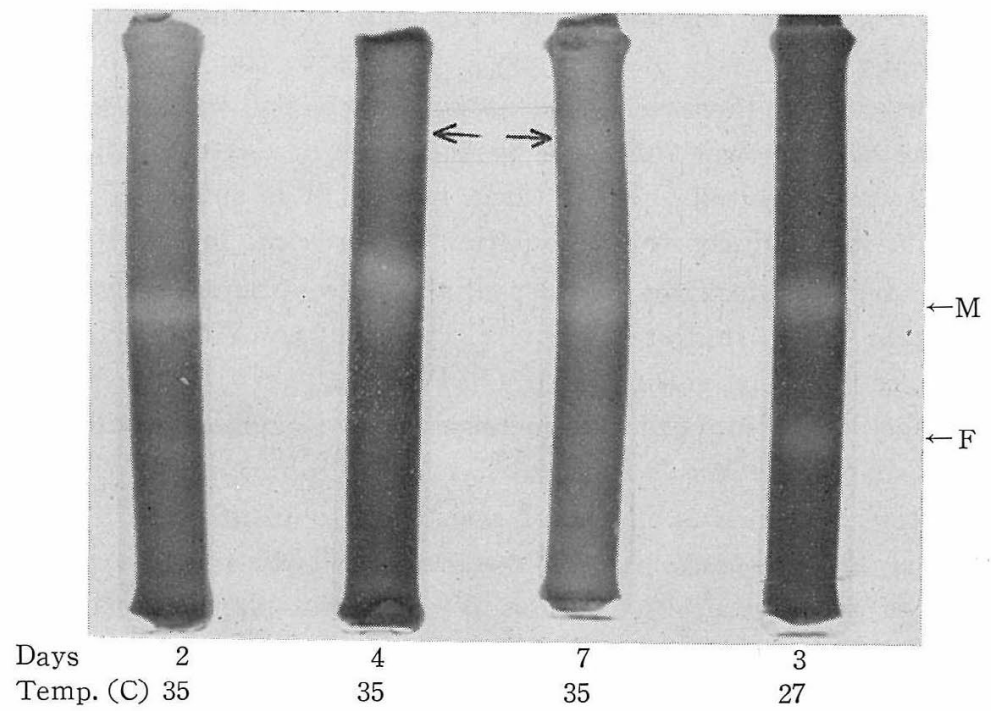

Fig. 5. Electrophoretic patterns of RNase isozymes in TMVinoculated leaves of $N$. glutinosa kept at the high temperature. After TMV-inoculation, $N$. glutinosa plants were incubated at $35 \mathrm{C}$ for 2,4 or 7 days. Arrow shows the new isozyme band. $\mathrm{M}$ and $\mathrm{F}$ show the isozyme bands, respectively.

\section{Effects of temperature on the behavior of the enzyme}

When $N$. glutinosa plants inoculated with TMV were kept at $35 \mathrm{C}$, no local lesions were formed on the leaves, but systemic infection occurred. As stated in the preceding section, the enhancement of $\mathrm{F}$ isozyme activity in the leaves inoculated with TMV was noticed on and after the time of local lesion appearance. It is interesting to determine whether or not such the high temperature treatment of the inoculated 
$N$. glutinosa effects on the enzyme activity, with special reference to the behavior of $\mathrm{F}$ isozyme activity. The high temperature had a very marked effect on the isozyme pattern. In this case, the band of $F$ isozyme was not detected, but a new faint band appeared on the upper position apart from the band of $\mathrm{M}$ isozyme 4 days after TMV. inoculation (Fig. 5). However, when TMV-inoculated plants kept for 2 days at the higher temperature were followed by transfer to the lower temperature, $21 \mathrm{C}$, local lesions were formed. In the electrophoresis of the enzyme preparation from such the plant leaves, the new band was not observed, but F isozyme appeared again.

\section{Discussion}

RNase activity in tobacco plant leaves increases with mechanical injury or TMVinfection of the leaves ${ }^{1,411)}$. In the present study, the same evidence was obtained on the enzyme of $N$. glutinosa leaves. However, the nature of the enzyme increased with mechanical injury is intrinsically different from one increased with TMVinoculation. The former induced the increase of $\mathrm{M}$ isozyme activity, and the latter $\mathrm{F}$ isozyme.

As shown in Fig. 1, the behavior of the enzyme after mechanical injury corresponded to the one of TMV-infectivity after injury. In Fig. 3, the electrophoretic profile of the enzyme showed the increase of $M$ isozyme activity with injury. In addition, when $M$ isozyme activity was inhibited by bentonite or dextran sulfate treatment, the viral infectivity was inhibited. From these results, it is suggested that the increase of $M$ isozyme activity induces the stimulation of the viral infectivity.

On the other hand, F isozyme activity of the leaves increased with yeast RNA- or eosine Y-treatment which inhibited the viral infectivity. Yeast RNA has been shown to be a resistance-inducing substance to TMV-infection ${ }^{2,7,10,16)}$. And, as previously stated, TMV-inoculation induced the increase of $\mathrm{F}$ isozyme activity. From such the evidences, it is suggested that $F$ isozyme has a role inhibitory to the virus infection. The hypersensitive response is a type of resistance to plant virus ${ }^{8)}$. It has generally been known that this response is not observed in TMV-infected $N$. glutinosa plant kept at the high temperature ${ }^{12)}$. When $N$. glutinosa plants inoculated with TMV were kept at such the temperature, $\mathrm{F}$ isozyme was not detected, but the new isozyme appeared. This evidence also supports that $\mathrm{F}$ isozyme may be participated in the resistance to TMV-infection.

Van Loon and Van Kammen ${ }^{15)}$ reported that four and three virus specific protein components were induced in Samsun NN and N. glutinosa after infection with TMV, respectively. In the present study, $\mathrm{F}$ isozyme may be identical to one of such the virus specific proteins, because the relative electrophoretic mobility of $F$ isozyme $\left(R_{f}\right.$ 0.77, data not shown) is the same as one of the proteins that they found. However, it is unknown on the function of the new isozyme. Elucidation on the question, hopefully, will be a result of a further study.

\section{Literature cited}

1. Bagi, G. and Farkas, G. L. (1967). Phytochemistry 6:161-169.

2. Cheo, P. C., Lindner, R. C. and McRitchie, J. J. (1968). Virology 35: 82-86. 
3. Davis, B. J. (1964). Ann. N. Y. Acad. Sci. $121: 404-427$.

4. Diener, T. O. (1961). Virology $14: 177-189$.

5. Fraenkel-Conrat, H. (1966). In Procedures in Nucleic Acid Research (Cantoni, G. L. and Davies, D. R. eds.). Harper \& Row publishers, New York and London. pp. 484-485.

6. Frisch-Niggemeyer, W. and Reddi, K. K. (1957). Biochim. Biophys. Acta 26: 40-46.

7. Gicherman, G. and Loebenstein, G. (1968). Phytopathology 58: 405-409.

8. Loebenstein, G. (1972). Ann. Rev. Phytopathol. 10: 177-206.

9. Markham, R. and Strominger, J. L. (1956). Biochem. J. $64: 46$.

10. Meneghini, M., Musumeci, M. R. and Moraes, W. B.C. (1969). Arq. Inst. Biol. (Sao Paulo) $36: 5-7$.

11. Reddi, K. K. (1959). Biochim. Biophys. Acta 33: 164-169.

12. Samuel, G. (1931). Ann. Appl. Biol. 18: 494-507.

13. Schlegel, D. E. (1960). Virology $11: 329-338$.

14. Steere, R. L. (1959). Adv. Virus Res. 6: 1-73.

15. Van Loon, L. C. and Van Kammen, A. (1970). Virology 40: 199-211.

16. Van Loon, L. C. (1975). Ibid. $67: 566-575$.

17. Wilson, C. M. (1971). Plant Physiol. 48: 64-68.

\title{
和 文 摘 要
}

\author{
タバコモザイクウイルス感染の Nicotiana glutinosa \\ 植物葉に特けるリボヌクレアーゼの挙動
}

松下亀久・下川英俊

付傷, 化学薬品処理, またはタバコモザイクウイルス（TMV）接種をした Nicotiana glutinosa 植物葉 のリボヌクレアーゼの挙動について研究した。本酵素の活性は付傷により増加し16時間後に Max に達した。 TMV も酵素活性の増加をひき起こしたが，その効果は接種原の濃度に依存的であった。本酵素は，ポリア

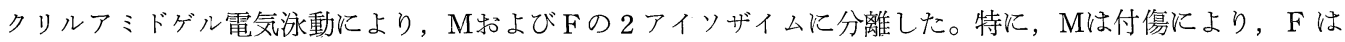
TMV の接種によって, それぞれ, 活性の増加が起こった。葉面の化学薬品処理に执いて, ベントナイト挔 よびデキストランサルフェートはMの活性を阻害し，一方，イースト RNA 拈よびエオシンYはFの活性を 増加させた。しかし，これらの薬品により TMV の感染性は阻害された。TMV を接種した本植物を $35 \mathrm{C}$ に打いて高温処理をしたとき（このとき，全身感染が起こった）Ｆの活性は検出されず，新たに別のアイ

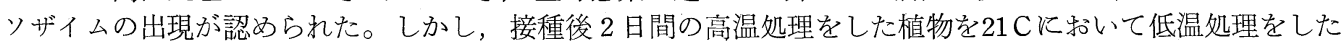
とき（このとき，局部病斑の形成が起こった），前述の新らしいアイソザイムの活性は認められなくなり，再 び，Fアイソザイムの活性が現われるようになった。以上の実験結果より，TMV の感染に和けるりボスク レアーゼの役割について考察した。 